\title{
CHEMICAL AND MICROSCOPIC ANALYSES OF THE AFGHAN TURKMEN ERSARI TRIBE HEADDRESS
}

\author{
Tereza Hejzlarová ${ }^{1}$ - Ján Vančo² - Michal Čajan ${ }^{1}$ - Zdeněk Trávníček ${ }^{1}$
}

\begin{abstract}
In accordance with the research plan of the Material Culture Unit within the framework of the project entitled 'Sinophone Borderlands - Interaction at the Edge', a study of the chemical composition and surface features of metal parts of the Afghan Ersari Tribe headdress was performed. The headdress consists of a textile base and ornamental metal decoration called gupba and a metal diadem called sünsüle. The obtained results of the analyses, using a scanning electron microscopy (SEM) equipped with an energy dispersive spectrometer (EDS) and an X-ray fluorescence (XRF) spectrometry, uncovered the microscopic features and composition of the metal pieces of the gupba and sünsüle. The main goal of the work was to reveal the chemical compositions of the metal parts in order to determine which metals and procedures were used over the course of their production and to support the current assumptions based on visual appraisals of objects of this type. These results undoubtedly broaden our view of the Turkmen culture in Afghanistan and help us form a database of knowledge and facts about artefacts from the Sinophone borderlands.
\end{abstract}

KEYWORDS: headdress - metal ornaments - Turkmens - Ersari - Afghanistan chemical analysis - microscopic analysis

\section{Introduction}

The Sinophone Borderlands - Interaction at the Edge project together with the Asian Studies Department, the Sociology and Cultural Anthropology Department and the Regional Centre of Advanced Technologies and Materials is jointly developing a Material Culture Laboratory that will contain equipment with the ability to analyze various artefacts gathered during ethnographic fieldwork. The Lab will be dedicated to illustrating concepts, theories, and studies of cultural anthropology (as well as archaeology and linguistics) in the artefacts. It will also focus on detailed material analysis which should corroborate hypotheses arising from social science and humanities approaches. The intent is to create cutting edge research possibilities and enhance the training experience of students and scholars in this newly opened field at Palacký University. Its

1 Contact: Tereza Hejzlarová \& Zdeněk Trávníček \& Michal Čajan, Department of Asian Studies, Faculty of Arts, Palacký University Olomouc, Czech Republic; e-mail: alabaj@email.cz, zdenek.travnicek@upol. cz, michal.cajan@upol.cz. The authors would like to acknowledge the financial support from the project 'Sinophone Borderlands - Interaction at the Edge' (grant No. CZ.02.1.01/0.0/0.0/16_019/0000791) granted by the Ministry of Education, Youth and Sports of the Czech Republic.

2 Contact: Ján Vančo, Division of Biologically Active Complexes and Molecular Magnets, Regional Centre of Advanced Technologies and Materials, Faculty of Science, Palacký University Olomouc, Czech Republic; e-mail: jan.vanco@upol.cz.

This work is licensed under the Creative Commons Attribution-Noncommercial-No Devivs 3.0 License 
aim is to promote scholarship, stimulate theoretical discussion, and provide chemical, anthropological, linguistic, or sociological explanations with an ethnological and geographical foundation. ${ }^{3}$

Within the scope of the project, we performed a material investigation on the headdress of Afghan Turkmen from the Ersari tribe dated back to the late 1930s. The investigated object is a female headdress with a typical metal decoration called gupba on its top and a metal diadem called sünsüle also belonging to the Afghan Ersari tribe and dated to the end of the twentieth century. Gupba is the decoration of the female headdress most frequently used among Turkmens consisting of a small metal cupola with pendants around its perimeter and a tube on its top where feathers of an owl or a falcon are fastened. If the feathers are missing, it means the girl is already engaged. The entire headdress with gupba was usually covered with silver coins. In the past, gup$b a$ was typical for a female headdress especially among the tribes Teke, Yomut, Saryk, and Ersari, ${ }^{4}$ Sünsüle (sinsile, silsile) is a metal diadem that was fastened or sewn to the headdress. It usually consisted of one or two rows of metal plates with a stamped ornament that were connected with chains with numerous pendants. Amongst certain Turkmen groups, the pendants were also on both sides of the diadem, hanging down to the shoulders. The plates in the middle and on both sides of the diadem were decorated with carnelian, turquoise, or coloured glass. Sünsüle was known to almost all Turkmen tribes; in many regions, it was worn by girls and women up until their first, or even second child was born. ${ }^{5}$

The origin and age of both objects were determined using a comparative analysis of image historical sources, material sources (artifacts), and expert literature. ${ }^{6}$ Attention was drawn to the period from the second half of the nineteenth century until the end of the twentieth century.

Material research utilizing analytical and imaging methods conducted in the chemical laboratory significantly extends the findings obtained by methods used by the humanities. To our best knowledge, based on the literature search, the studied objects were not yet investigated using SEM/EDS and XRF techniques. The aim of the work was to support the current assumptions regarding the chemical compositions of the metal parts of the gupba and sünsüle and provide the obtained results for further investigations of such a type of material.

It needs to be noted that a number of expert publications dealing with Turkmen jewellery focus almost exclusively on Turkmen jewels made of silver and Turkmen jewellery manufacturing in Turkmenistan. Our study is a contribution to the investigation of materials and jewellery-making techniques of Afghan Turkmens, whose jewellery manufacturing has been only a marginally researched and insufficiently investigated topic.

\section{Turkmen Jewellery - Materials and Techniques}

Turkmen jewels are typified especially by their robust but elegant form, a combination of characteristic materials and a specific manufacturing technique. Jewels played an

3 For more information see: https://sinofon.cz/.

4 Васильева 1979, p. 178.

5 Ibid., p. 180.

6 Private collector, Prague. Both the headdress and the diadem were acquired independently of each other. Afghan coins from 1937 used as decorative elements were a helpful feature when dating the headdress. 
important role particularly in the life of Turkmen women. They not only had an aesthetic function, but also a magic-related meaning. The number and type of jewellery also determined the social status of its bearer. In the past, women wore jewels not only for ceremonial occasions, but even in daily life. Jewellery sets worn for ceremonies were obviously more sumptuous and apart from normally worn rings and necklaces they also included massive wristbands and robust neck jewellery as well as various decorations placed on the headdress. Another common practice was sewing of small silver plates onto the front part of the clothing. The number of jewels worn depended on the wealth of the particular family, but even the poorest ones tried to procure them for their women. The most sumptuous jewellery sets with a weight of approximately twenty kilograms were worn by brides. ${ }^{7}$

Turkmen jewellery is generally characterized by a consistent style, but also differences in processing technique, materials, and ornaments related to the specifics of jewellery making of the individual Turkmen tribes [Tab. 1].

Tab. 1. Major Differences between Jewellery-Making Techniques of Selected Turkmen Tribes. ${ }^{8}$

\begin{tabular}{|c|c|c|}
\hline Tribe & Techniques & Example \\
\hline Teke & $\begin{array}{l}\text { engraved gilded } \\
\text { ornament }\end{array}$ & \\
\hline Yomut & $\begin{array}{l}\text { golden plates with } \\
\text { stamped patterns }\end{array}$ & \\
\hline Ersari & $\begin{array}{l}\text { absence of engraved or } \\
\text { gilded ornament }\end{array}$ & \\
\hline Salor & $\begin{array}{l}\text { engraved not gilded } \\
\text { ornament }\end{array}$ & \\
\hline
\end{tabular}

7 Khramov 2003, p. 27.

8 Sources for photographs: Teke and Yomut - Collection of the Náprstek Museum, inv. č. A 15 318, inv. č. 57357 (Photo Jiř́ Vaněk), Ersari - available at: https://www.palmbeads.com.au/products/tribal-turkoman-ersari-asyk, Salor - available at: https://coyotespaw.com/Detailed/231.html. 
Typical jewellery-making techniques used by Turkmens include engraving, stamping, gilding, openwork, and filigree. The jewellery production of individual Turkmen tribes can be identified according to the techniques and the decoration style used. The largest Turkmen tribe Teke, for example, decorated engraved floral or geometric ornaments with gilding, while with Salors and Saryks, the engraved ornament was not gilded. Yomuts created the ornaments using thin golden plates of various forms decorated with stamped patterns fused to the silver base. The jewellery of the Turkmen tribe Ersari is typified by its considerable simplicity, little decoration, and absence of engraved ornaments or gilded elements. The characteristics of the ornament are another feature different for each tribe. Complex ornaments consisting mostly of floral patterns are typical for the Teke tribe, while Yomuts, Ersaris, and Saryks used prevalently geometric ornaments, mostly diamonds, triangles, and circles.

The most frequently used material in Turkmen jewellery manufacturing was silver; gold was used especially for decorating the silver base due to its high price. Golden jewellery was generally very rare with Turkmens, including for instance small earrings or rings. Gemstones were an important type of decorative element. Turkmen jewellery makers used carnelians in particular, while turquoise was less typical. Amongst the less wealthy social strata, jewels were usually made of silver-plated copper, and a substitute for gemstones was coloured glass, more recently even plastic. Turkmen jewellers frequently worked to order and material was usually brought by the customers themselves. This is the reason why old decorations and silver coins were smelted when manufacturing a new jewel. A typical jewel for the majority of Turkmen tribes (Teke, Yomut, Saryk, Choudor, Ersari, Nokhurli etc.) was a massive silver one; only small tribes and some kin from the region around Chardzhou (present day Türkmenabad) and in the delta of the middle Amu Darya wore jewels from beads and coins more frequently. ${ }^{9}$

Jewels of Afghan Turkmens have preserved their original form and style differences related to the individual Turkmen tribes. At present, most Turkmens live in the provinces Herat and Balkh, with smaller groups also in the province Kunduz. Throughout their history, Turkmens came to Afghanistan in various periods and waves, but their most important migration took place at the end of the nineteenth century due to Russian expansion into Central Asia and as a consequence of the Basmachi Revolt in the 1920s and 1930s. The largest group of the population living here has always been that of the Ersari tribe, with other tribes living in the territory of Afghanistan being for instance Salors, Saryks, Teke, Yomuts, and others. ${ }^{10}$ The northern and north-western parts of the area are inhabited, apart from Turkmens, by Uzbeks and Tajiks, ${ }^{11}$ and particularly by Afghan nomads commonly called Kuchi. ${ }^{12}$ The elemental compositions of the metal parts of the Turkmen headdress and diadem correspond to those found in Kuchi jewels;

9 Васильева 1973, p. 91.

10 Бабаева 1985, p. 131.

11 The influence of Uzbeks and Tajiks on the analysed Turkmen headdress is obvious from the fabric on the rear side of the headdress covering the nape. It is decorated with an embroidery typical for Uzbeks and Tajiks but completely atypical for Turkmens. According to the material research in the collection of Central Asia jewellery owned by the National Museum - Náprstek Museum, the vast majority of Turkmen, Uzbek, and Tajik jewellery was manufactured from silver, often gilded. Part of Uzbek and Tajik jewels was prevalently from brass, nickelled brass, copper, and tin, see Hejzlarová, Pospísilová 2012, p. 91.

12 The name Kuchi is used mainly for Pashtun nomads from the tribal confederation Ghilji, but they can also incorporate other nomadic ethnic groups. 
this tribe used most frequently the alloy of copper, zinc, and nickel, and possibly also other metals, known as alpacca, paktong, new silver, etc. In the case of both the Kuchi and Turkmens, if silver was used, it was obtained from smelted old silver jewels or silver coins. ${ }^{13}$

As concerns the materials used, the jewels of Afghan Turkmens in both museum and private collections include silver and gilded ones, as well as those from alloys of base metals decorated with coloured glass instead of gemstones. These differences in the used materials clearly reflect the economic conditions of the individual Turkmen groups and their societal structure.

\section{Materials and Methods}

\section{The object under study}

The studied girl gupba headdress originates from the Turkmen minority (Ersari tribe) in Afghanistan. The maximum length from the top to the end of the textile base is $75 \mathrm{~cm}$ and the average diameter of the gupba is $22 \mathrm{~cm} \mathrm{[Pl.} \mathrm{1].} \mathrm{The} \mathrm{materials} \mathrm{of} \mathrm{the} \mathrm{headdress}$ include the cotton and wool textile base covered by round metal plates connected by metal chains. Some of the metal plates bear a flower motif produced by stamping or pressing. The two larger round metal plates decorated with flower motifs are accompanied by Afghan coins with 25 pul denomination from the Mohammed Zahir Shah kingdom era (AH 1316/ 1937 CE) with soldered loops. ${ }^{14}$ The top of the headdress is completed by the usual dome supplemented by several chains of orange beads. The front part of the headdress includes the full-metal diadem (sünsüle) composed of larger metal sheets decorated with gems (probably carnelians, and other red and green minerals or coloured glass pieces) and smaller metal plates, some of which were decorated by a flower motif produced by stamping or pressing, interconnected with ornate chains.

\section{X-ray fluorescence spectroscopy}

The average elemental composition of the headdress sample details has been determined by X-ray fluorescence (XRF) spectroscopy, using a Vanta Education spectrometer (Olympus, USA) calibrated for coinage metals and alloys and general mineralogy samples by the BAS a.s. company according to the ISO 9001:2015. The XRF spectrometer was equipped with $4 \mathrm{~W}$ rhodium X-ray source working at up to the $40 \mathrm{kV}$ excitation voltage and a large silicon drift detector. The final data, including the standard deviations, are a result of three independent measurements from the different spots in the same detail.

\section{Scanning electron microscopy (SEM) and energy-dispersive spectrometry (EDS)}

The SEM measurements were performed using the VEGA 3 LMU series microscope (Tescan, Czech Republic) equipped with $\mathrm{LaB}_{6}$ cathode and a series of integrated detectors, i.e. a secondary electron (SE) detector and a back-scattered electrons (BSE) detector, using the $30 \mathrm{kV}$ beam accelerating voltage and Wide-Field scanning mode to obtain the micrographs of selected headdress details.

13 Krzywicka 2012, p. 14.

14 Cuhaj 2009, pp. 26, Item no. KM\# 940. 
The energy-dispersive spectroscopy results were obtained by the Quantax 200 spectrometer (Bruker, USA) equipped with XFlash ${ }^{\circledR 6} \mid 10$ detector, used as an additional detector for the VEGA 3 LMU microscope. The EDS spectra were obtained using the exhaustive automatic acquisition mode in the range of $0.25-20.00 \mathrm{keV}$ by the acquisition of the signals from the whole area of the specific details obtained by the mapping of the elements (vide infra). The elemental composition, which characterizes the average composition of the selected detail in the headdress, was determined using the Esprit 1.9 software (Bruker, USA) by the standardless PB-ZAF method from the deconvoluted background-free spectra corrected for Bremsstrahlung and tilt angle of $-18^{\circ}$. The EDS spectrometer was calibrated for the specific measurement region $(20 \mathrm{keV})$ using the $\mathrm{K} \alpha$ of copper at $8.0463 \mathrm{keV}$.

The mapping of the selected elements in the samples was performed using the Esprit 1.9 software in mapping mode using the $0.3 \mathrm{~s}$ point time. The specific metals for mapping were selected by the qualitative analysis of the EDS spectrum obtained in the first few cycles of mapping. The final map was produced from the SE detector micrograph overlaid with the EDS detection results.

\section{Results and Discussion}

The investigation of the female gupba headdress and sünsüle diadem was focused on a characterization of its selected parts, dominantly metal ones, along with the beads and stones. The concrete parts under study are shown in Pls. 1-5 and were characterized using X-ray fluorescence (XRF) spectroscopy, scanning electron microscopy (SEM) and energy-dispersive spectrometry (EDS) which was used for elemental mapping. We wish to note here that based on the main constructional differences between both the devices and different methodological approaches by the acquisition of the elemental composition data by each of the methods, it is impossible to compare the obtained quantitative results directly (as for \% content), because each of the instruments is able to characterize the composition in different depths of the studied materials and also averages the composition from the different area of the corresponding artefact detail. There are no doubts, however, that the results originating from the above-mentioned techniques should be in a general in accord as for qualitative composition. The results of the XRF analyses are summarized in Tab. 2 and clearly represent the chemical compositions of the individually selected components. It is evident from Tab. 2 that the metal parts, bell (1), dome (2), and round metal plate with flower motifs (7) and metal rhombic sheets $(9,10)$, of the headdress can be described as alloy brass parts, consisting mainly of the elements copper (60.63-75.62\%), zinc (12.42-22.92\%), and nickel (3.52-14.76 \%) with a small addition of aluminium (0.74-1.08\%), silicon (0.15-2.62 \%), and in the case of bells (1) and round metal plates with flower motifs (7) also silver (0.15 $\%$, and $8.94 \%$, respectively) and tin (1.03-1.23\%). In the case of the metal plates with flower motifs (7), the nickel content is minimal (down to $0.11 \%$ ), whilst the coin (6) is composed mainly of copper $(72.90 \%)$ and nickel $(19.51 \%)$ with a small addition of aluminium $(1.46 \%)$ and silicon $(2.89 \%)$. 


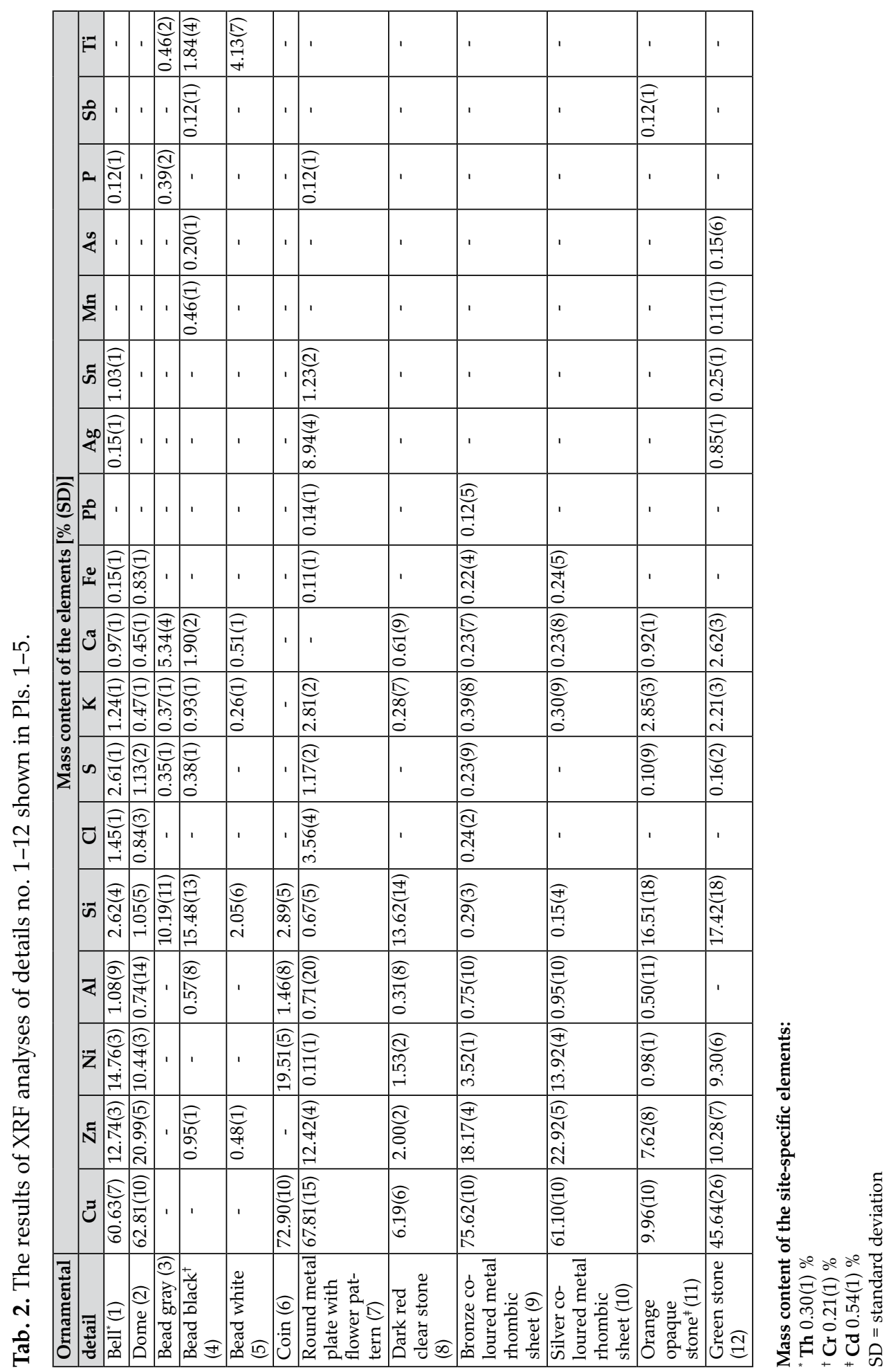


In the specific case of the larger bells (1), a higher content of thorium (0.30\%) was detected. In contrast, no other parts contained such high amounts of thorium. This might indicate that these parts might originate from a different craftsman or even a different region of western Afghanistan, where the thorium levels in the minerals (Sweeney 2007) were identified up to 20 ppm.

The SEM images of the coin (6) are shown in Pl. 6, the EDS spectra are depicted in Fig. 1., while the mapping of the elements, showing the presence of the selected metals and part of the chain connecting the individual parts of the headdress, is visualized in Pl. 7. The EDS spectra reveal that the alloy is composed predominantly of copper and nickel which is in accordance with the data obtained using XRF [Pl. 7, Tab. 2]. The mapping of the elemental content on the surface of the coin (6) revealed an interesting feature of the thin silver-plating layer [Pl. 7].

We also observed that the rhombic metal plates of the metal diadem exhibit diverse colours. The majority of them are silver-coloured (10). As concerns the composition of the bronze-coloured metal rhombic sheet (9), the results of XRF confirmed that its elemental composition is somewhat different, while the content of copper $(75.62 \%)$ is significantly higher and the nickel content in this plate is significantly lower (3.52 \%) than in silver-coloured metal plates [Pl. 8, Tab. 2], which in all probability influences the final colour of the corresponding part. Pl. 8 also shows the elemental composition of solder used to bind the holder to the metal pieces. It contains mainly the following elements: silver, aluminium, and silicon, which might mean that the hard-soldering technique with aluminosilicate flux has been used in the production process of these metal ornaments. The same solder matter was used to bind the holder for stones, for example (8), to the metal basin [Pl. 9, Figs. 1-3].

In addition to the metal parts of the gupba, the textile part of the hair dress is decorated with laces with larger beads of light-grey opaque colour (3) and smaller black (4) and white-coloured beads (5). The elemental composition of these beads [Tab. 2, items (3), (4), and (5)] indicates that they consist of variously stained glass types, while the light-grey staining was achieved by the addition of titanium oxide $(\mathrm{w}(\mathrm{Ti})=0.46 \%)$, and calcium oxide $(\mathrm{w}(\mathrm{Ca})=5.34 \%)$, and phosphates $(\mathrm{w}(\mathrm{P})=0.39 \%)$ to the glass, the white-colour was achieved mostly by the addition of titanium oxide $(\mathrm{w}(\mathrm{Ti})=4.13 \%)$ and zinc oxide $(\mathrm{w}(\mathrm{Zn})=0.48 \%)$. The black-colour of the beads was achieved by the addition of a mixture of titanium oxide $(\mathrm{w}(\mathrm{Ti})=1.84 \%)$, zinc $(0.95 \%)$, manganese $(0.46 \%)$, arsenic $(0.20 \%)$, and antimony $(0.12 \%)$ in the form of oxides or more likely as part of alumino-silicate mineral $(\mathrm{w}(\mathrm{Al})=0.57 \%)$. The compositions containing these elements are commonly detected in historic glasses, as documented by Schalm et al. (2011: 103) in the samples originating from fifteenth-seventeenth centuries.

\section{Conclusions}

One of the aims of the work was to analyse the metal parts of the headdress and diadem with an accent on their microscopic features and compositions. The obtained results helped to reveal not only the composition of the parts (alloys), using SEM/EDS and XRF techniques, but also indirectly to point out the craftsmanship of the metal parts of the examined things. As is generally accepted, the chemical and microscopic analyses are widely utilized during the study of articles of a museum character. These analyses were done with the purpose of supporting and further specifying the assumptions and conclu- 
Fig. 1. EDS spectra of the coin (6) (measured - top, deconvoluted - down) showing the peaks of the main constituents of the metal alloy. The normalized mass content of the main constituents calculated from the deconvoluted spectrum above: $\mathrm{w}(\mathrm{Cu})=72.0 \%$, $\mathrm{w}(\mathrm{Ni})=23.1 \%, \mathrm{w}(\mathrm{Si})=1.4 \%, \mathrm{w}(\mathrm{Ag})=1.3 \%$, and $\mathrm{w}(\mathrm{Al})=0.5 \%$.
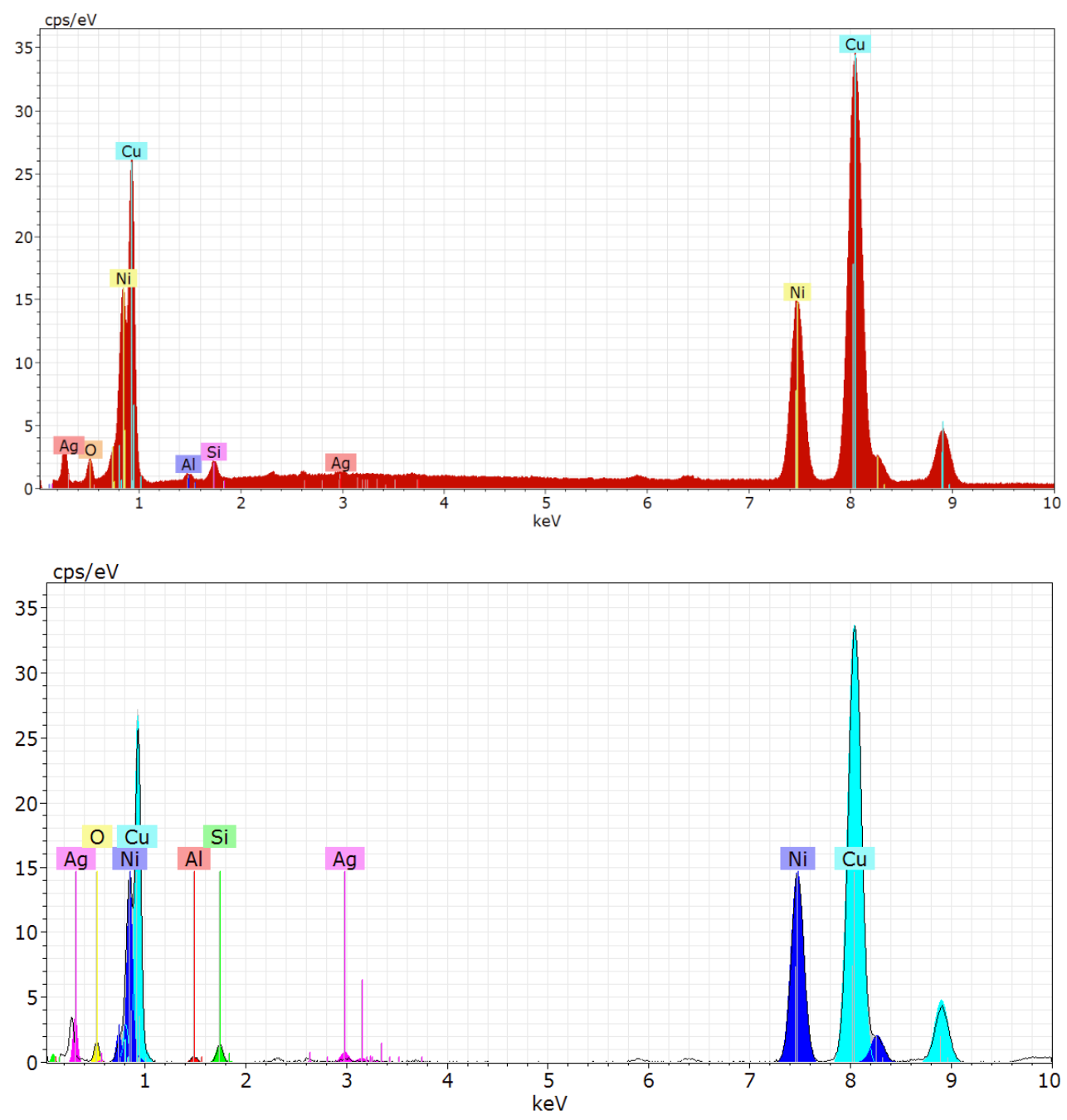
Fig. 2. EDS spectra of solder matter (measured - top, deconvoluted - down) containing the peaks of the main constituents originating from the solder, flux, and metal-based background. The normalized mass content of the main constituents calculated from the deconvoluted spectrum above: $\mathrm{w}(\mathrm{Ag})=39.7 \%, \mathrm{w}(\mathrm{Al})=13.8 \%, \mathrm{w}(\mathrm{Cu})=8.0 \%, \mathrm{w}(\mathrm{Zn})=$ $3.3 \%, w(S i)=2.0 \%$, and $w(N i)=0.9 \%$.
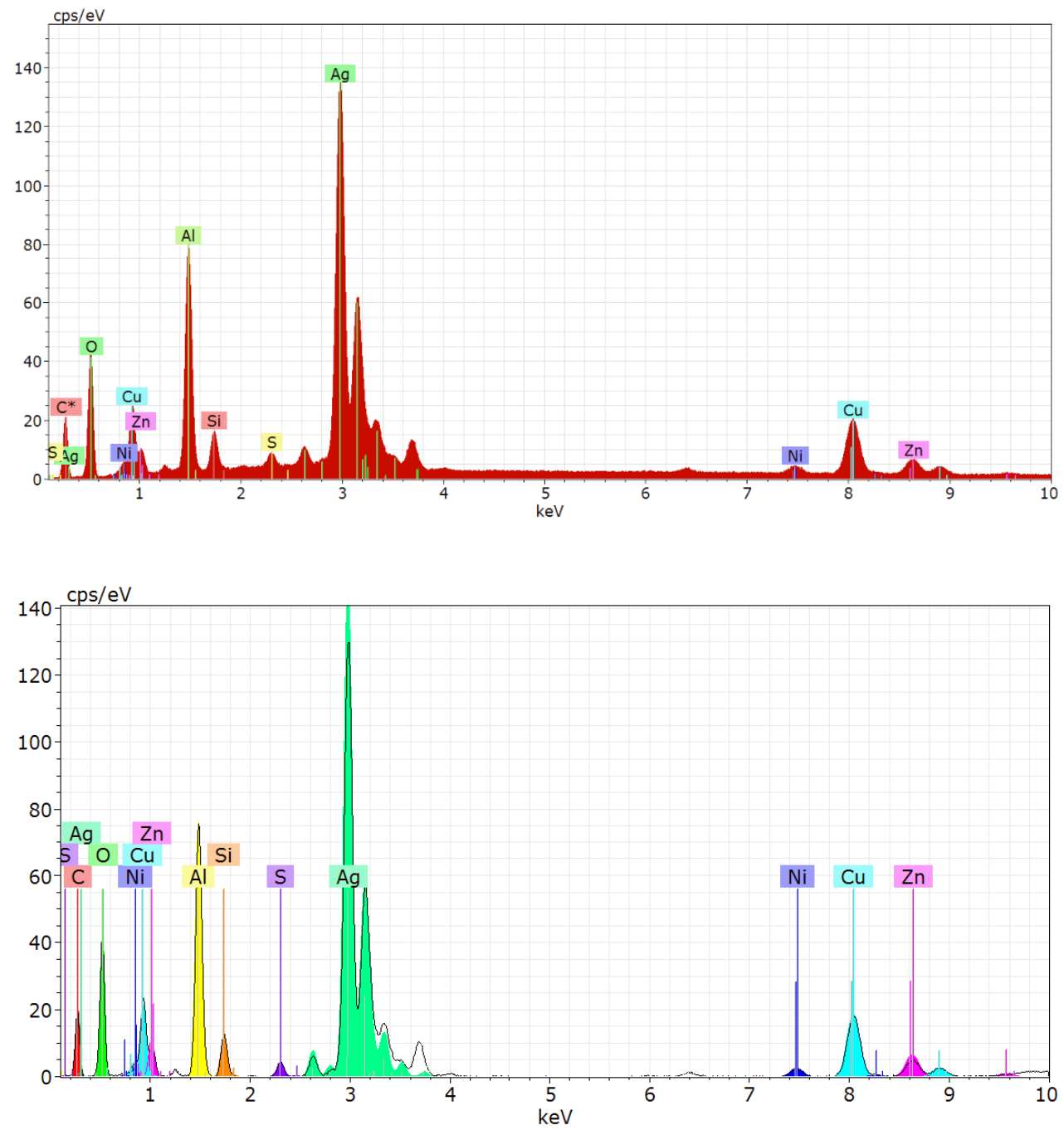
Fig. 3. EDS spectra of the gem holder soldered on the silver coloured metal sheet background (10) (measured - top, deconvoluted - down) showing the peaks of the main constituents. The normalized mass content of the main constituents calculated from the deconvoluted spectrum above: $\mathrm{w}(\mathrm{Cu})=46.3 \%, \mathrm{w}(\mathrm{Zn})=19.5 \%, \mathrm{w}(\mathrm{Ni})=9.3 \%, \mathrm{w}(\mathrm{Ag})$ $=5.6 \%, \mathrm{w}(\mathrm{Si})=4.2 \%$, and $\mathrm{w}(\mathrm{Al})=2.7 \%$.
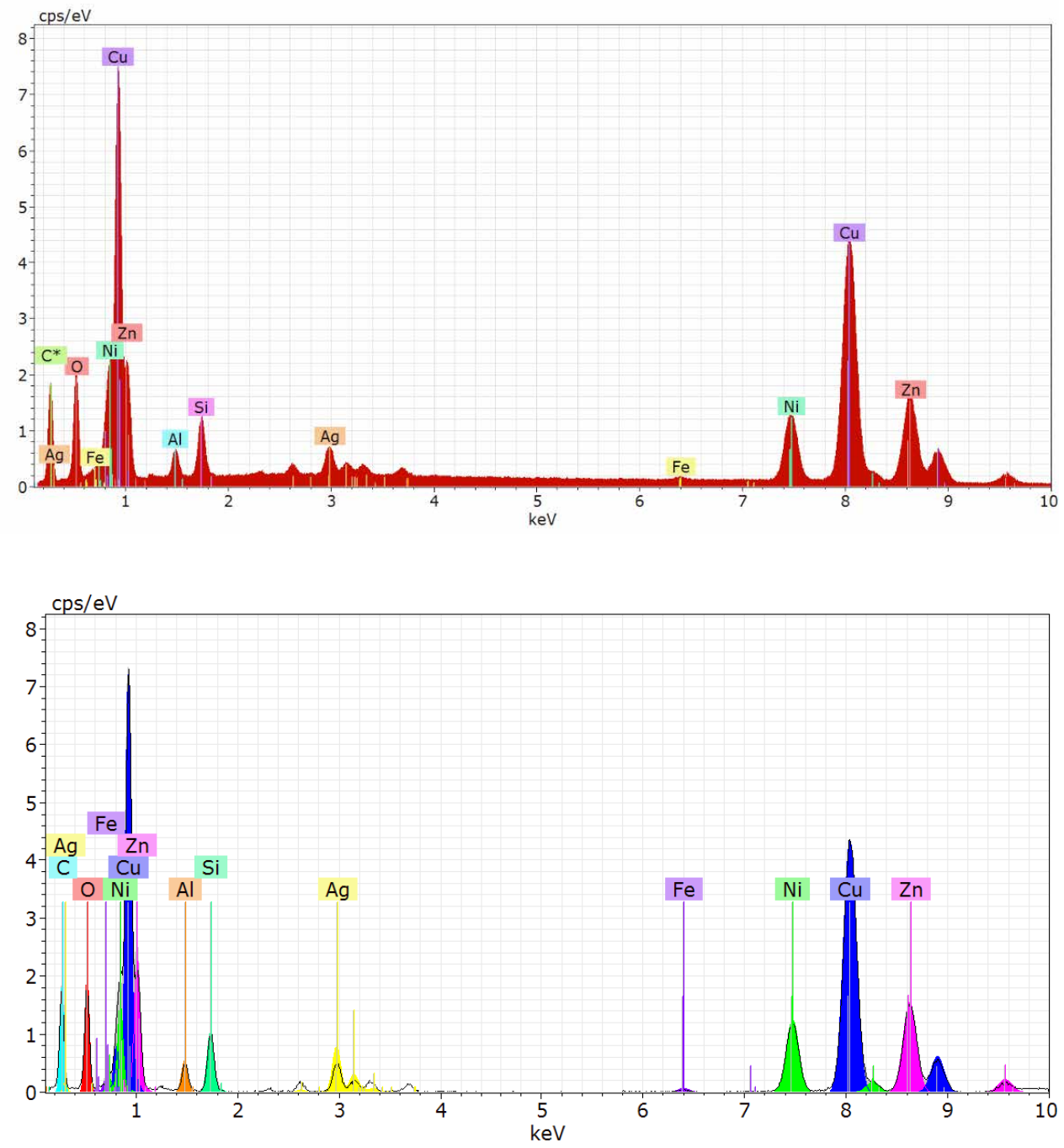
sions which are related to the material, territorial, and time classification of investigated artefacts. These products can be described and classified from both ethnological and artistic points of view, however, the utilization of scientific experimental methods helps to quantify the obtained data and thus, some assumptions can be confirmed or disproved. For a closer classification of an object, e.g. its geographical origin, it is appropriate to combine the above stated methods; the reason is especially that the migration of craftsmen for various history-related reasons resulted in a transfer of manufacturing and decorating techniques. The more material analyses available to us, the better we can identify particular objects even in wider historical-cultural contexts. This contribution presents the results of interdisciplinary collaboration between the humanities and natural sciences which assists in the expansion of experimental data in the field of material research of artefacts of a museum character, being limited accessible. This also applies to data related to jewellery manufacturing in the community of Afghan Turkmens which has not been sufficiently investigated thus far. Our study therefore represents one of the first analyses of the particular artifacts and provides data for further research.

\section{Literature:}

Бабаева, А. К. (1985) Туркмены Афганистана: история расселения, племенной состав, очерк политической истории 20-30-х годов XX века, диссертация кандидата исторических наук. Москва

Cuhaj, G. S., Michael, T. (2009). 2010 Standard Catalog of World Coins: 1901-2000. Krause Publications, 37 ${ }^{\text {th }}$ edition, pp. 26, Item no. KM\# 940.

Hejzlarová, T., Pospíšilová, D. (2012) Czech Travellers and Collectors in Central Asia. Collections of the National Museum-Náprstek Museum, Prague. Prague: National Museum

Khramov, V. (2003) Türkmen zergärçilik sungaty halkymyzyň kalbynyň aýnasydyr. Aşgabat: Türkmendöwlethabarlary

Krzywicka, K. (2012) Bizuteria etniczna Afganistanu ze zbiorów Muzeum Azii i Pacyfiku w Warszawie. Warszawa: Muzeum Azii i Pacyfiku w Warszawie

Pospíšilová, D. (2013). Aplikace exaktních metod při určování kovových předmětů z Indie a Blízkého východu. In: L. Pech, ed., Tradice a inovace v kulturách starého Východu, Západočeská univerzita, Plzeň, pp. 17-26.

Pospíšilová, D., Pech, M., Kotyk, M. (2016). The use of non-destructive instrumental methods in the determination of metal objects from the Asian collection of the Naprstek Museum., Annals of the Naprstek museum, 37(1), pp. 79-88.

Seiwert, W. (2009) Jewellery from the Orient: Treasures from the Dr. Bir Collection, Stuttgard: Arnoldsche

Schalm, O., Proost, K., De Vis, K., Cagno, S., Janssens, K., Mees, F., Jacobs, P., Caen, J. (2011). Manganese Staining of Archaeological glass: the characterization of Mn-rich inclusions in leached layers and a hypothesis of its formation. Arhaeometry 53(1), pp. 103-122.

Sweeney, R., Kucks, R. P., Hill, P. L., Finn, C. A. (2007). OF 2007-1042: Radiometric 
Survey in Western Afghanistan: A Website for Distribution of Data, version 1.0, Denver, Colorado: U.S. Geological Survey, Available at: http://pubs.usgs.gov/of/2007/1042 [Accessed 10 July 2020].

Сычева, Н. (1984) Ювелирные украшения народов Средней Азии и Казахстана ХІХХХ веков из собрания Государственного музея искусства народов Востока. Москва: Советский художник

Васильева, Г. П. (1973) Туркменские женские украшения. Советская этнография, № 3, c. $90-98$.

Васильева, Г. П. (1979) Головные и накосные украшения туркменок XIX-первой половины XX в, in: Сухарева, О.А. (отв. ред.) Костюм народов Средней Азии. Историко-этнографические очерки. Москва: Наука, с. 174-204. 


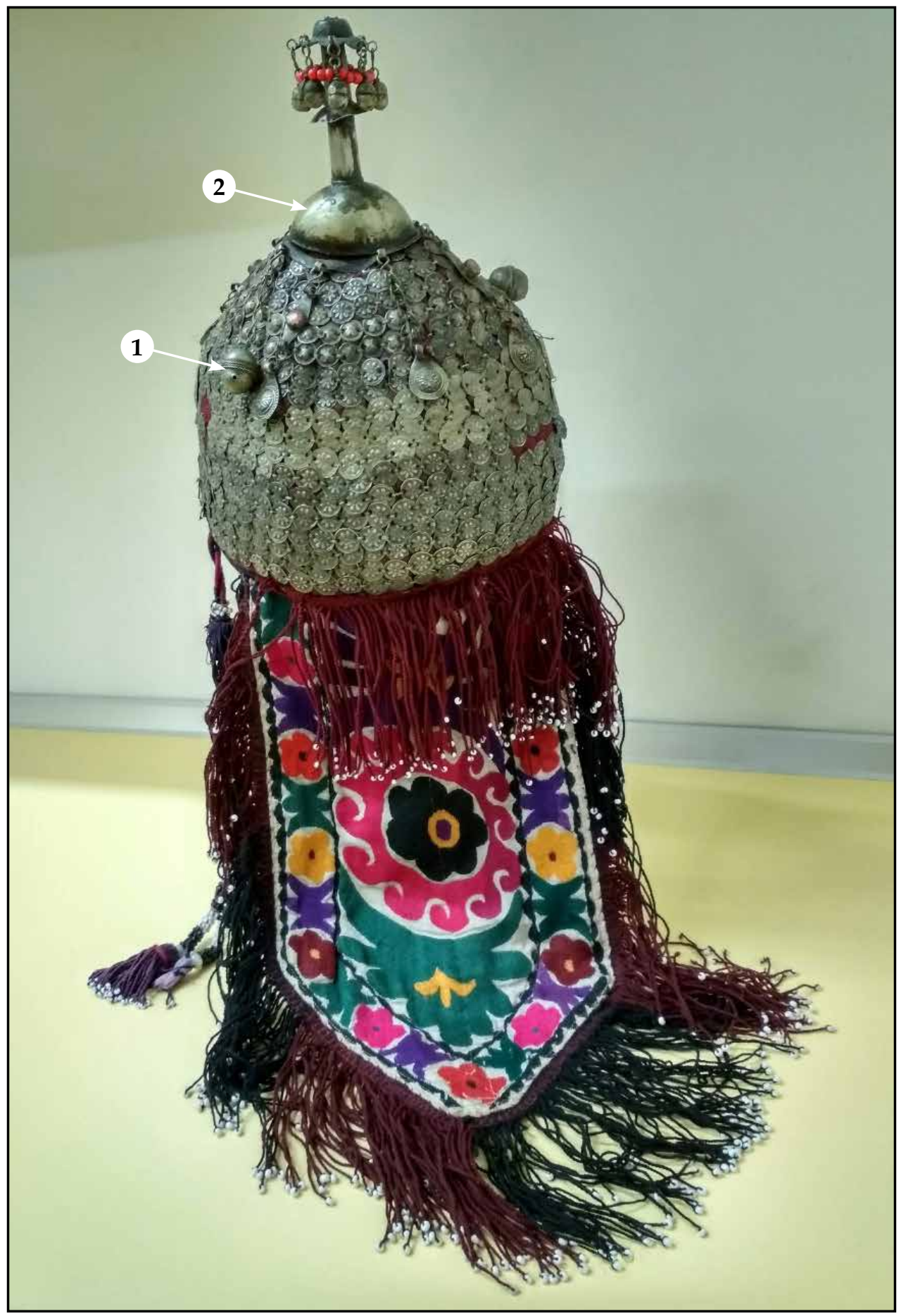

Pl. 1. Photograph of the Turkmen headdress pointing out the studied details (1-2). 


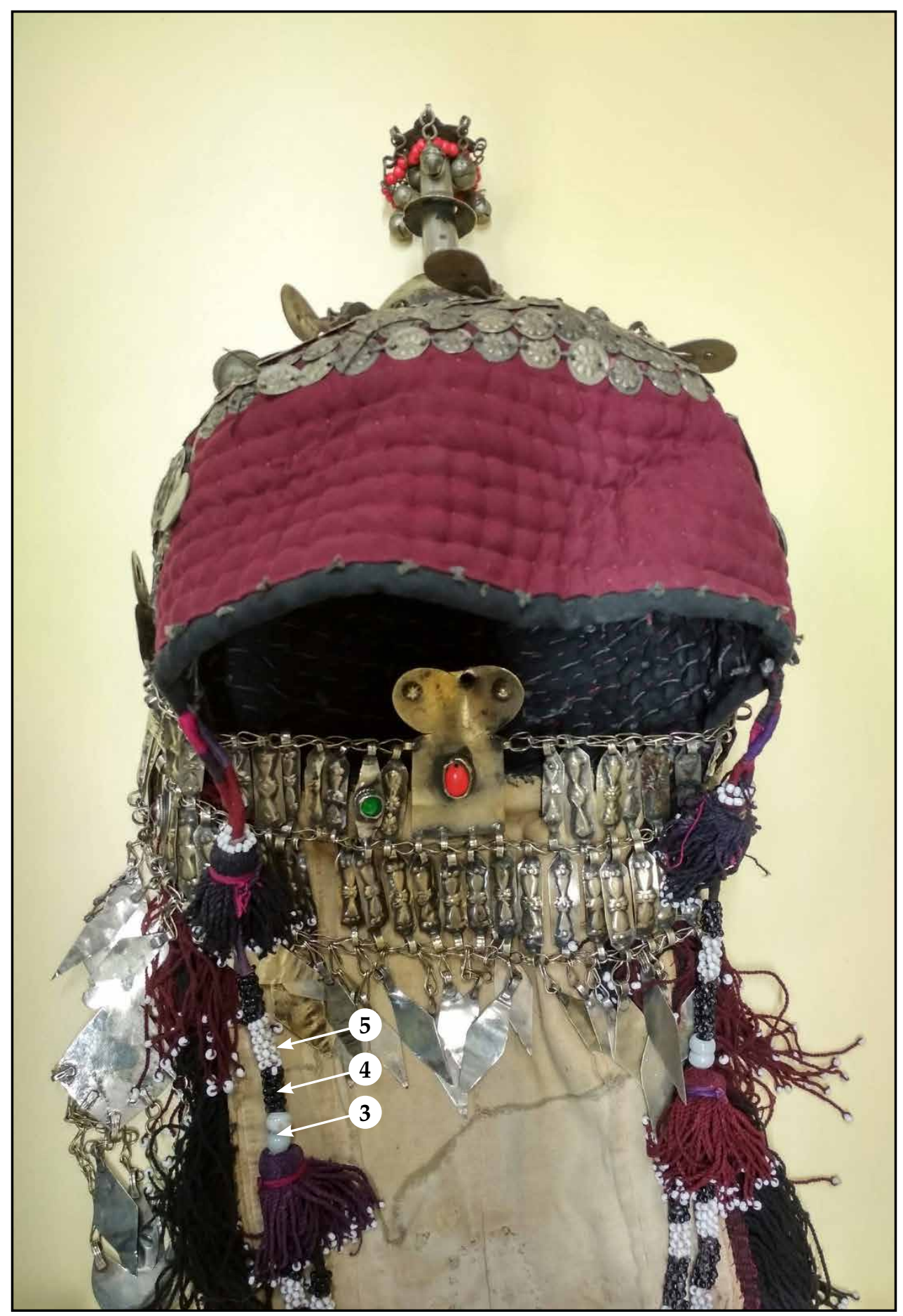

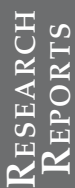

Pl. 2. Photograph of the front part of the headdress showing the sünsüle diadem and pointing out the studied details (3-5). 


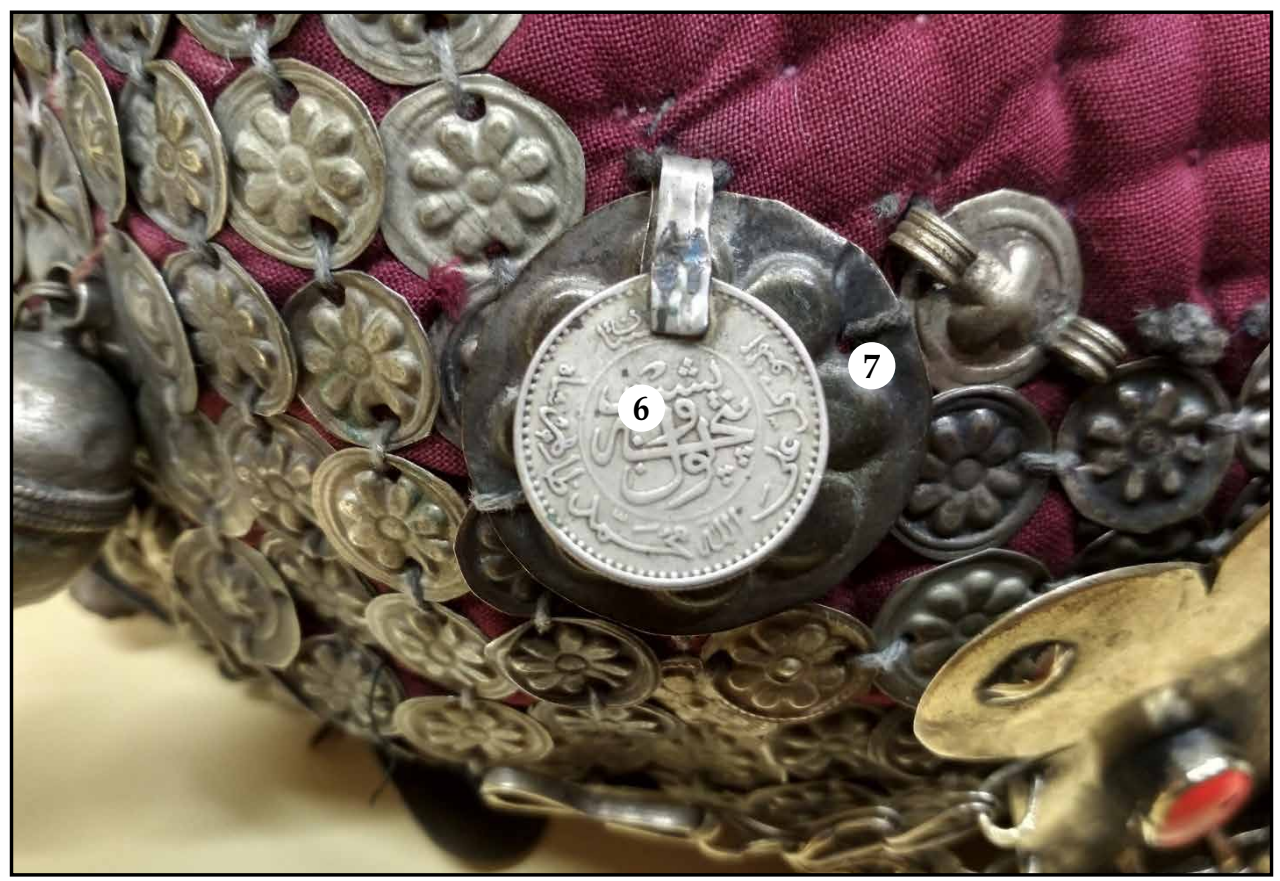

Pl. 3. Photograph of the side part of the headdress showing the reverse of the 25 pul coin (detail 6, top-down) and detail (7).

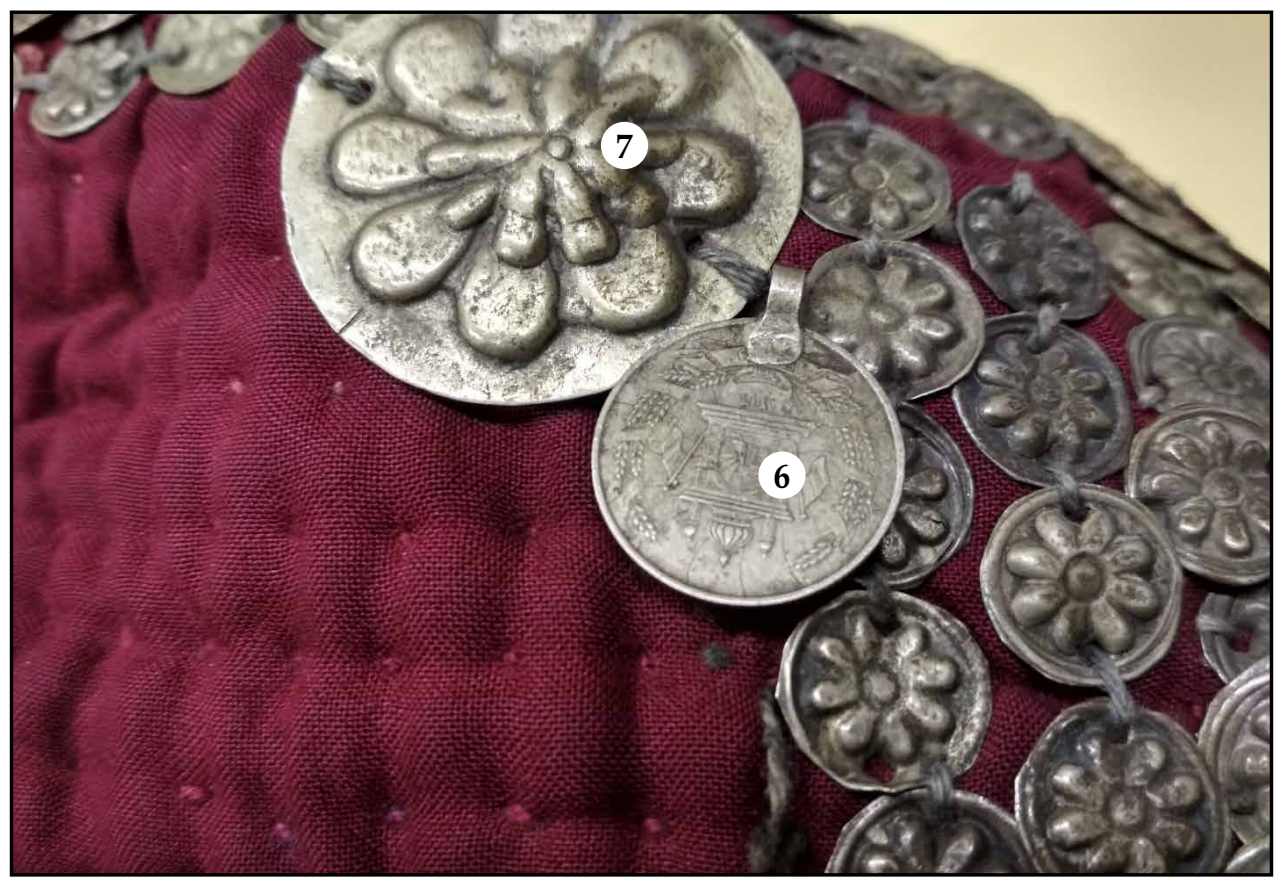

Pl. 4. Photograph of the side part of the headdress showing a different view on the detail (6) (obverse of the 25 pul coin, top-down) and detail (7). 


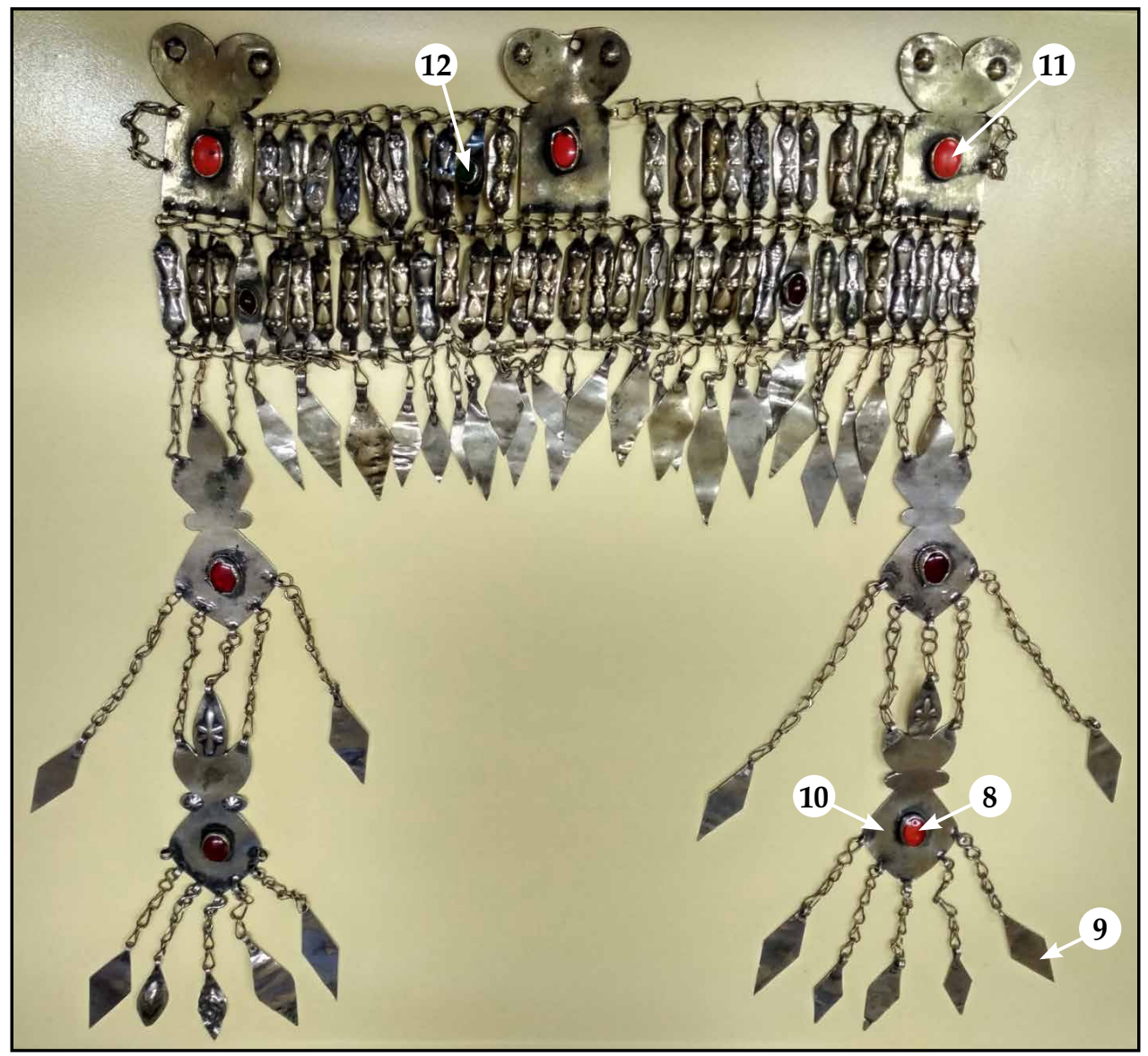

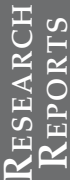

Pl. 5. Photograph of the detached metal diadem from the front part of the headdress showing the studied details $(8-12)$. 


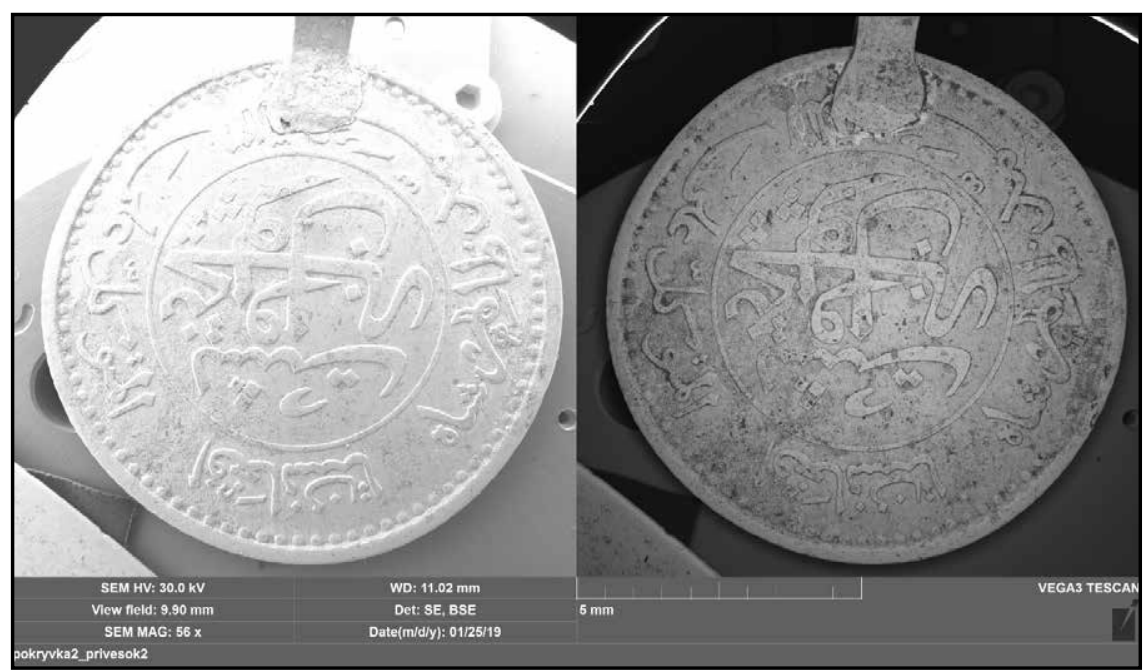

Pl. 6. SEM images of the coin (6) obtained using SE detector (left) and BSE detector (right).

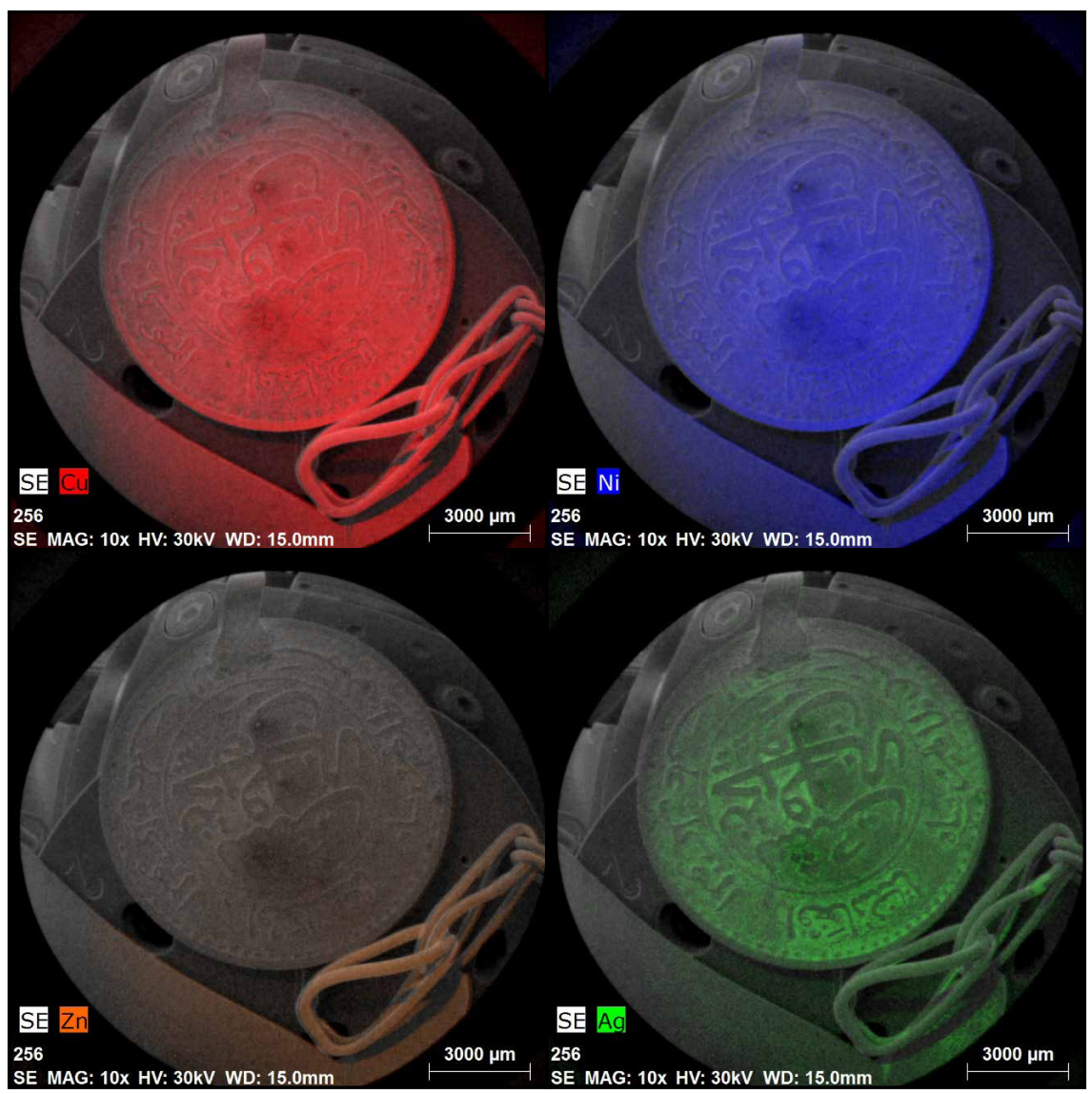

Pl. 7. Mapping of the elements by means of SEM/EDS microscopy showing the presence of the selected metals in the coin (6) and part of the chain connecting the individual parts of the headdress. 

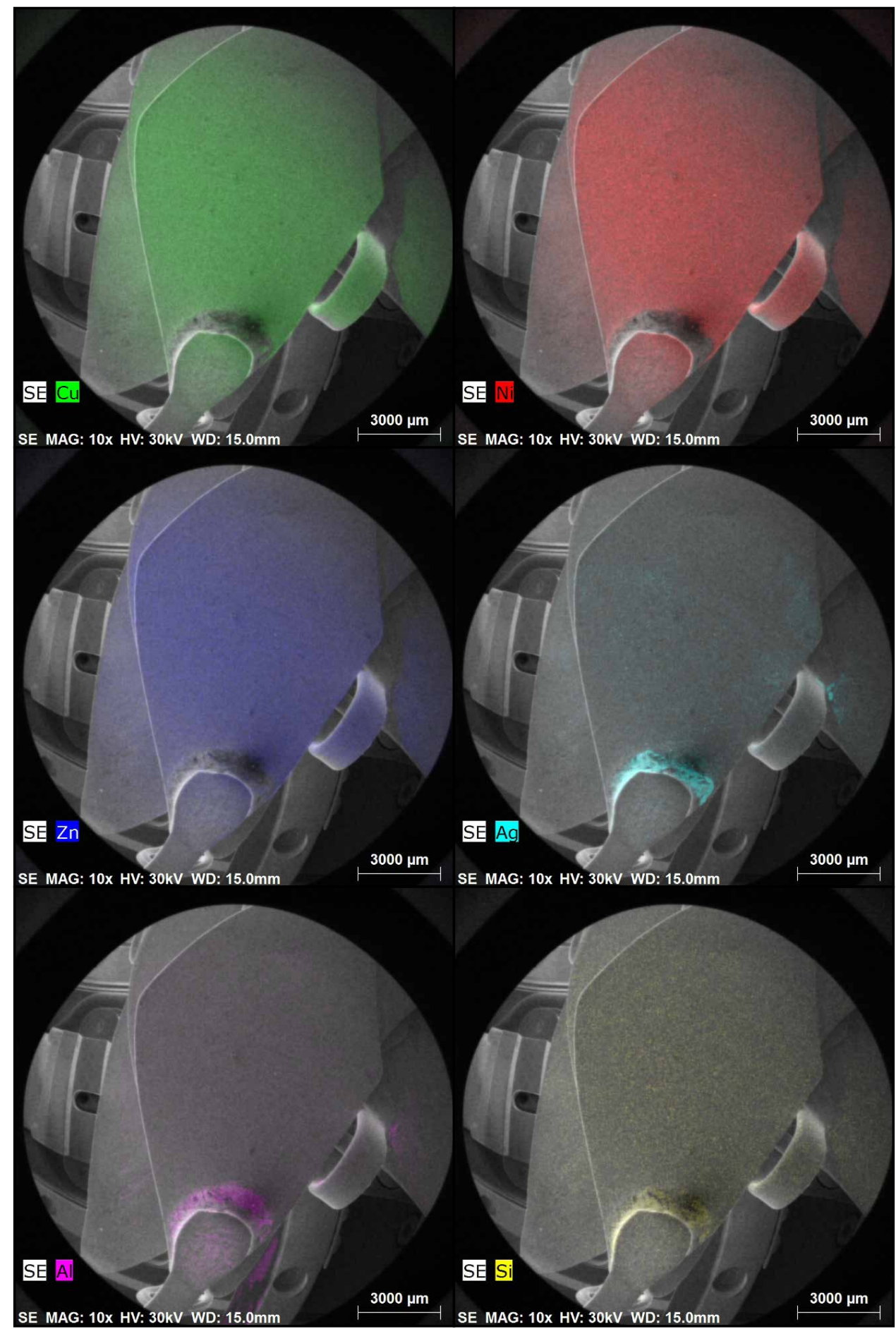

SE MAG: $10 \mathrm{x}$ HV: $30 \mathrm{kV}$ WD: $15.0 \mathrm{~mm}$

Pl. 8. Mapping of the elements by means of SEM/EDS microscopy showing the presence of selected metals in the bronze coloured metal sheet (9). 


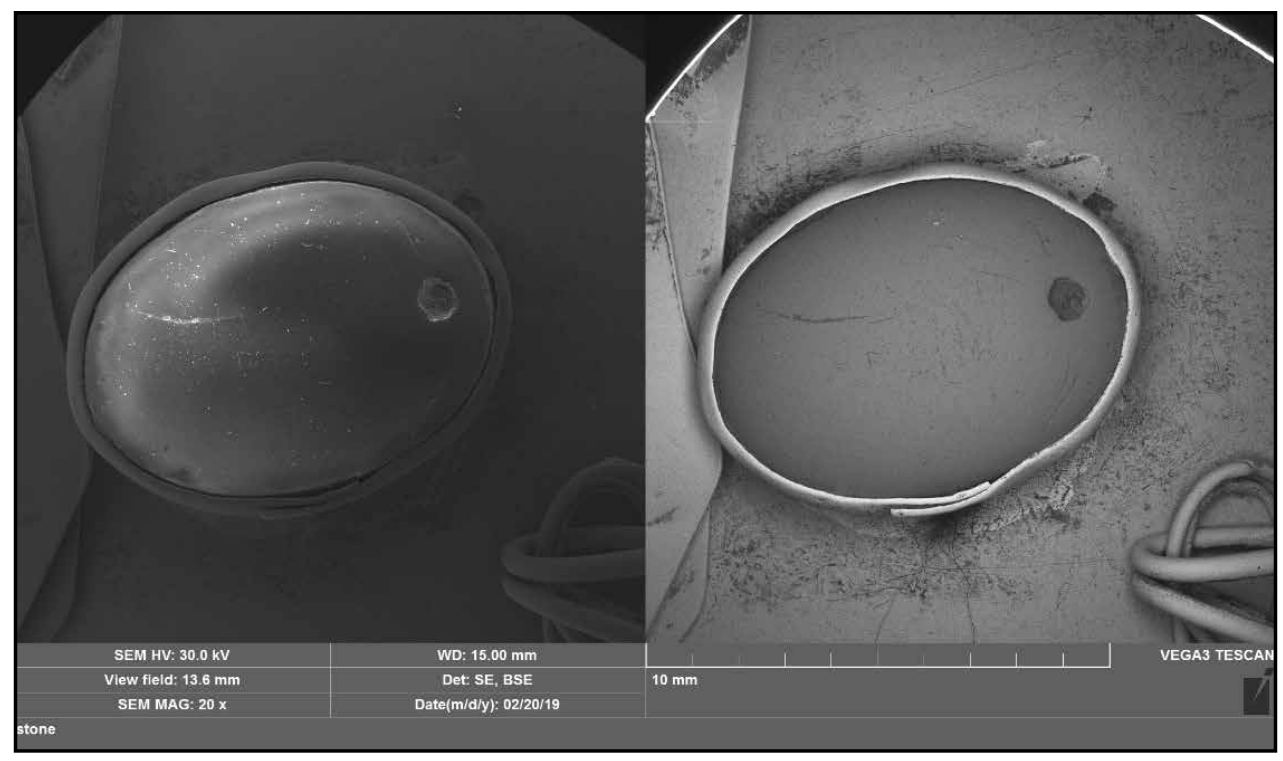

P1. 9. SEM images of dark red clear stone (8) together with the silver coloured metal sheet background (10) obtained by SE detector (left) and BSE detector (right). 